DOI: $10.21554 /$ hrr.091805

\title{
THE FREQUENCY OF USAGE OF DIFFERENT WORK FORMS IN AN INCLUSIVE TEACHING ENVIRONMENT
}

\section{Saša Stepanović ${ }^{1}$}

Elementary School 'Mladost”, Belgrade, Serbia

\author{
Original scientific paper
}

\begin{abstract}
The aim of this study was to investigate how frequently the different forms of work (frontal, individual and group) are used in the Serbian inclusive education. The sample consisted of 16 elementary schools in Serbia which pupils with sensory impairments attend (visual and auditory impairments: N=69). Systematic observation has been used on 382 classes. Results have shown that in the majority of classes the frontal form was predominantly used (67.7\%). Significantly less present was the individual form (22.6\%), while the variations of group work were the least frequently used. Considering the goals of inclusive education with the fact that the social engagement of pupils with sensory impairments in class can be beneficial, the frontal form alone is not enough for an effective teaching process. Despite its practicality, it is necessary to use the frontal form in balance with other work forms in all the phases of the class.

Keywords: frontal work form, group work form, inclusion, individual work form, pupils with sensory impairments, work forms of teaching

\section{INTRODUCTION}

Forms of teaching represent basic didactic strategies that enable learning while being based on a communication structure between teacher and pupils (Pranjić, 2005). Despite their numerous classifications (Meyer, 2002), within Serbian didactic literature they are organized around the number of pupils involved during class. In relation to this criterion, we can distinguish between frontal, individual and group form (which includes teamwork and working in pairs). The frontal form (teacher's presentation) has risen in significance since the implementation of Comenius's school system into mass education, be-

cause it was in accordance with education goals at the time (Sadler, 2014). However, this traditional approach to teaching that still predominantly relies on this form is criticized for being unable to answer the demands of the modern age. In education today, the focus is transferred onto functional knowledge, rather than a purely theoretical one. Meeting these modern educational demands, the work distribution and organization of the class is essential (in terms of the activity carrier). The usage of various teaching forms has many important consequences on the learning process and its outcome, as well as the overall communication in the classroom (teacher-student and peer relations).
\end{abstract}

\footnotetext{
${ }^{1}$ Correspondence to:

Saša Stepanović, Elementary School "Mladost", Serbia

Gandijeva 99, Belgrade, Serbia

E-mail: salenono86@gmail.com
} 
Their adjusted and balanced combination is also highly relevant in the inclusive environment that gravitates around the equal involvement of every child in the learning process, regardless of their impairments or disabilities. For pupils with sensory and other impairments, it is important to ensure and organize a teaching climate that produces a feeling of belonging and equality, stimulating them to fulfill their potentials and move the boundaries of their limitations. To put an idea of inclusion into practice, implementing different forms of work plays a fundamental role because they move the emphasis to the number of acters and their interaction, simulating life beyond school walls. This means that communication and understanding, in their basis, must be adjusted to every type of impairment. Pupils with impairments should be provided with a number of preconditions of a complex support, ranging from the design of special plans and programs, using different teaching tools, prompts and technology, to the adequate evaluation of proficiency (Mitchell, 2008). If pupils with impairments are not provided with a proper way of following the class (which is, in part, enabled by the diverse work forms), they can significantly fall behind. This can negatively reflect on their motivation, sociability, self-efficiency and finally, on the effectiveness of the inclusive education itself. In short, the education of pupils with sensory impairments should be directed towards the optimal development of their personality and potentials (Hrnjica, 1997).

As mentioned above, the frontal form of teaching relates to the teachers' presentation that pupils listen to, watch and remember (Ruić, 2006; Radović, 2005) and it is dominant in Serbian pedagogical practice (Markić, 2014; Buljubašić Kuzmanović \& Petrović, 2014). This form is used to introduce new or summarize old material, as well as for detailed explanation and description of drawn conclusion or facts. If the quality of teaching is to be obtained using this form, several conditions must be met. Teacher's diction should be clear, his voice loud enough and the speech understandable and appropriate to the age of the pupil group. This especially holds when a pupil with a hearing impairments attends class, taking into account the risk of misunderstanding or dropping back. Further, it is useful if the teacher gives his own opinion about the subject, uses different demonstration techniques and constantly encourages the curiosity of pupils (Bognar \& Kragulj, 2010). Further advantages of this form concern time efficiency and the control the teacher has over the classroom dur- ing work. Implemented correctly, it can prove very efficient (Bligh, 1998). However, the nature of the frontal form is such that it implies a unidirectional teacher-student relation (Terhart, 2001), thereby ignoring the social nature of learning (Rowland, 1987). If it is overused, it can put a limit on the communication in the classroom. Additionally, the frontal form is designed for an "average" student, which is not conducive to the heterogeneous structure of an inclusive classroom. Based on the aforementioned, negative consequences of the asymmetric use of the frontal form are the rigidity and lack of flexibility of the teaching process, distancing students among themselves and the teacher. In the course of conductive inclusive teaching, the frontal form shows considerable limitations. Within its scope, pupils with impairments can have fewer opportunities for socializing and collaborative learning, can linger on through certain topics, have trouble understanding or ultimately, without assistance or adapted teaching, remain unable to fully follow the class work.

Contrary to the frontal form, group form allows for direct interaction to occur (i.e. horizontal and vertical, two-way communication) by dividing pupils in work groups of various sizes. While the groups of a couple of pupils are customary, group form has many variations within itself, mainly teamwork and working in pairs. In teamwork, pupils embrace a common goal that, in order to be completed, needs the full cooperation of every member and the coordination of available materials and time. The roles assigned to each pupil are somewhat different, but tightly connected, allowing everyone to contribute to the work process, despite the fact that usually one pupil has the lead role. In working in pairs, pupils collaborate and adapt to one another while working on the shared goal. They directly become familiarized with the other's strengths and weaknesses and use them as resources, thus strengthening the relationship. This work sub-form can serve as a preparation for group work involving more children (Mattes, 2007). As such, it gives a notable insight into a peer's mind that is more or less different. For pupils with sensory impairments, working in pairs can serve against prejudice and in favor of social inclusion. Therefore, the collaborative nature of group work has a strong positive influence on peer relations, as well the process and the outcome of learning. Through the conception of common goals, cognitive processes are activated while the pupil gets pushed into diverse practical activities. In return, a more firm knowledge is constructed. 
There is a tremendous body of research that proves this and many other benefits of the group work form, among which only few are specified here: pupils become more independent, responsible, creative and self-confident (Dean, 2000); they learn to respect individual differences, which can lead to greater empathy, fruition of friendships (Gödek, 2004; Gerard \& Miller, 1976), and positive attitudes towards social heterogeneity (Johnson et al., 1976); they quickly and more efficiently establish knowledge and skills (Slavin, 1987), in which social skills stand out as most improved (Hallam, Ireson \& Davies, 2013). Obviously, a number of inclusion requests can be answered through the appropriate usage of the group form, which has more social "success" than any other form. All of its variations encourage social and intellectual skills highly applicable to the present and future everyday life. However, in working with certain materials it is best replaced by other forms. These are the materials too demanding or abstract, and those who require a certain training first. Even the very dynamics of the group can lead to a halt when, for instance, the less competent pupils rely too much on the more competent, or when some pupils express very high sensitivity. Nevertheless, the richness of communication that group work possesses can have a positive influence on the motivation, success and the social participation of pupils with sensory impairments. Even outside the educational system, these (developed) skills and abilities can, in the long-term, potentiate success and satisfaction in other aspects of life. As the school, being a type of preparation for the community and a small community within itself, uses the essential components of adaptation, in its basic element (the class), they must be organized in a way that enables pupils with sensory impairments to leave the system of schooling as self-confident, accepted, active members of the society.

Individual form refers to the pupil's independent work on specific classroom assignments. It allows pupils to work with the speed they are comfortable with and distribute the energy and time needed for completion autonomously. Most commonly, it is used in lesson revision, application of knowledge on different problems, in constructing individual projects and working on the computer. It also serves as a replacement for tasks unsuitable for group work, and as a preparation for the test-situation (Buljubašić Kuzmanović \& Petrović, 2014). Pupils advantages cover the advancement of organizational skills, critical thinking, knowledge application and gaining re- sponsibility (Meyer et al., 2008). They become capable of adequate auto-evaluation (Kyriacou, 2009). In using the individual form, it is necessary to adapt the type of a task and its complexity to the pupil, which in the context of inclusive education can include some transformations (in terms of used materials, helping tools, additional teacher's help). Hence, pupils with sensory impairments and their progress needs more attention, motivation maintenance and determination of the stable evaluation standard. Nurturing their self-efficacy is crucial, which is accomplished with patient and solid pedagogical practice. However, in tracing the work of every individual pupil, time-management can become an issue if the teacher were to spend more time on some pupils and less on others (Galton \& Williamson, 1992). The prevention of this asymmetry can be achieved with giving sufficient support, and with directing pupils to additional help after class, for instance. But the biggest objection to this form remains the lack of social interaction. Even though pupils learn and develop different skills on their own, the communication and perspective sharing with others is of immeasurable value. Social relations are the central component of a knowledge that is functional.

When it comes to applying the described forms in class, the teacher should bear in mind that they require prudence and even certain artistry. That means that the usage of teaching forms goes way beyond the simple placement of a pupil with sensory impairments in a group or a team, or giving them individual work for the sake of the individual form itself being fulfilled. If the teaching is to be efficient, the teacher should coordinate all possible forms and use them in an approximately equal amount. Besides their described individual positive effects, it is their diversity that influences many other aspects of the didactic culture of the school (Kolak, 2012). Organizing classes so that pupils can feel integrated in the community that designs the best environment for them to learn is an essential quality of inclusive teaching. In that way, pupils with sensory impairments are preparing for the professional and social interaction in the community (Alper \& Ryndak, 1992).

This research aims to gain a realistical insight into the presence of frontal, individual and group work form in the inclusive teaching in Serbia, using the frequency of usage and their duration in class as measures. Along with their strenghts and weaknesses, the present research tends to provide relevant indications for improvement by comparing the frequency of different work forms usage. 
Following the class while only partly relying on the senses can potentially threaten the socialization, independence and success of these pupils; with the investigation of diversity of work forms used in an inclusive environment, this research indirectly tends to point to the relevance of combining them in class, in terms of prevention. So far, the research that included pupils with sensory impairments (in more or less similar research topics) remains scarce. The change this research makes by including the whole category of sensory impairments and exploring different forms of work used while working with them can make a contribution to a better quality of Serbian teaching practice.

\section{MATERIALS AND METHOD}

\section{Sample}

The sample consisted of 16 elementary schools in the Republic of Serbia, which are attended by pupils with sensory impairments. The choice of schools was made according to available information on the overall number of pupils with sensory impairments. Research was conducted using the technique of systematic observation which covered 382 school classes. Within these observations, there were 200 observations of the sixth grades and 182 observations of the seventh grades (Table 1).

Table 1. Observations per grade

\begin{tabular}{lccc}
\hline & Grade & f & \% \\
\hline Sixth & 200 & 52.4 \\
Seventh & 182 & 47.6 \\
\hline Total & 382 & 100.0 \\
\hline
\end{tabular}

The sample of pupils with sensory impairments $(\mathrm{N}=69)$ cosisted of blind $(7,2 \%)$, low vision $(50,7 \%)$, deaf $(17,4 \%)$ and partially deaf $(24,6 \%)$ pupils. The structure of the sample according to the type of impairments is presented in Table 2 .

Table 2. Type of impairments

\begin{tabular}{|c|c|c|}
\hline Type of impairments & f & $\%$ \\
\hline Blind & 5 & 7.2 \\
\hline Low vision & 35 & 50.7 \\
\hline Deaf & 12 & 17.4 \\
\hline Partially deaf & 17 & 24.6 \\
\hline Total & 69 & 100.0 \\
\hline
\end{tabular}

\section{Research technique}

Systematic observation has been used, which falls into the category of descriptive methods. It was carried out through the protocol of teaching process recording and it consists of different guidelines for following and describing the adaptability and organization of the classroom, and forms of communication between pupils and teachers. This technique was chosen because it was assessed as appropriate for the given research goal. Systematic observation provided a direct examination of the teaching process that was strictly limited to forms of work (frequency and duration). In other words, it gave useful insight into the subject of research. The observation unit was the whole class, separated into introduction, central and final part of the class. For the given subject, the usage of descriptive statistics were appropriate (frequencies, percentiles, measures of central tendency and dispersion).

\section{RESULTS}

The results show that, looking at the class as a whole, the frontal form is predominantly used. Individual form is the next most often used form, and teamwork and group work follow. Working in pairs is the least used form. The results are presented in Table 3. As it can be seen, on the two-thirds of observed classes the frontal form is most commonly used. Other forms are used in significantly less degree. Looking at the introductory part of the class, the frontal form is predominant again. Despite that, the individual form, that comes second by frequency, takes more time. Frontal form and teamwork follow, while the group work has the shortest duration. Working in pairs was not used in this part of the class. Conclusively, teachers have consistently chosen to use the frontal form as the introduction to class subject. 
Table 3. The frequency of teaching form usage - general information ${ }^{2}$

\begin{tabular}{|c|c|c|}
\hline Dominant teaching form & f & $\%$ \\
\hline Frontal & 776 & 67.7 \\
\hline Individual & 259 & 22.6 \\
\hline Teamwork & 77 & 6.7 \\
\hline Group & 19 & 1.7 \\
\hline Working in pairs & 15 & 1.3 \\
\hline Total & 1146 & 100.0 \\
\hline
\end{tabular}

The frequency of introductory teaching forms is presented in Table 4, and their duration is shown in Table 5. In the central part of the class, the frontal form was still used most often, but the frequency of individual form use has increased, being almost equal with the frontal form in terms of frequency. Teamwork and

group form have been rarely practiced, while working in pairs was the least used. In this part of class, all forms had similar duration. However, the individual form lasted the longest. Working in pairs lasted somewhat shortly, following the frontal form and teamwork, while the group form had the shortest duration.

Table 4. The frequency of teaching form usage - introductory part

\begin{tabular}{lccc}
\hline & Dominant teaching form & f & $\mathbf{\%}$ \\
\hline Frontal & 329 & 86.1 \\
Individual & 37 & 9.7 \\
Teamwork & 15 & 3.9 \\
Group & 1 & .3 \\
\hline Total & 382 & 100.0 \\
\hline
\end{tabular}

Table 5. The duration of teaching forms in the introductory part of class

\begin{tabular}{lccccc}
\hline & Duration of teaching forms & Min & Max & M & SD \\
\hline Frontal & 1.00 & 32.00 & 7.32 & 3.89 \\
Individual & 2.00 & 45.00 & 7.77 & 9.04 \\
Group & 2.00 & 2.00 & 2.00 & .00 \\
Teamwork & 2.00 & 10.00 & 6.67 & 2.99 \\
\hline
\end{tabular}

The data on the frequency of usage is not signifi- have been presented in Table 6 . cantly different from the introductory part, and they

Table 6. The frequency of teaching form usage-central part

\begin{tabular}{lccc}
\hline & Dominant teaching form & f & \% \\
\hline Frontal & 175 & 45.8 \\
Individual & 164 & 42.9 \\
Teamwork & 34 & 8.9 \\
Group & 6 & 1.6 \\
Working in pairs & 3 & .8 \\
\hline Total & 382 & 100.0 \\
\hline
\end{tabular}

${ }^{2}$ The total number of observation refers to the observations of introductory, central and final parts of class taken together. 
Table 7 shows the duration of teaching forms in the central part of the class. Lastly, in the final part of the class the frontal form is predominantly used. The individual form comes after, but in a notably less extent. All of the group forms are present in a negligible small degree. Frontal form also has the longest duration range, which potentially indicates its practical and easy application when the control of the available time is in the teacher's hands.

Table 7. The duration of teaching forms in the central part of class

\begin{tabular}{lcccc}
\hline \multicolumn{1}{c}{ Duration of teaching forms } & Min & Max & M & SD \\
\hline Frontal & 2.00 & 45.00 & 18.66 & 10.10 \\
Individual & 2.00 & 45.00 & 19.98 & 11.08 \\
Group & 5.00 & 30.00 & 14.08 & 7.60 \\
Working in pairs & 5.00 & 30.00 & 19.33 & 9.30 \\
Teamwork & 3.00 & 35.00 & 17.64 & 9.58 \\
\hline
\end{tabular}

The frequency of teaching forms is shown in Ta- quently in the final part of class, the teachers still ble 8, and their duration in Table 9. Conclusively, do not experiment with other forms of work sufdespite the fact that group form is used more fre- ficiently.

Table 8. The frequency of teaching form usage - final part

\begin{tabular}{lccc}
\hline & Dominant teaching form & f & \% \\
\hline Frontal & 272 & 71.2 \\
Individual & 58 & 15.2 \\
Teamwork & 28 & 7.3 \\
Group & 12 & 3.1 \\
Working in pairs & 12 & 3.1 \\
\hline Total & 382 & 100.0 \\
\hline
\end{tabular}

Table 9. The duration of teaching forms in the final part of class

\begin{tabular}{|c|c|c|c|c|}
\hline Duration of teaching forms & Min & $\operatorname{Max}$ & $\mathbf{M}$ & SD \\
\hline$\overline{\text { Frontal }}$ & 2.00 & 25.00 & 5.68 & 3.10 \\
\hline Individual & 2.00 & 15.00 & 6.42 & 4.18 \\
\hline Group & 10.00 & 15.00 & 12.50 & 3.54 \\
\hline Working in pairs & 5.00 & 10.00 & 7.50 & 3.54 \\
\hline Teamwork & 2.00 & 10.00 & 4.90 & 2.02 \\
\hline
\end{tabular}

\section{DISCUSSION}

This study investigated the frequency of usage of different teaching forms in an inclusive practice, with an emphasis on the pupils with sensory impairments. Since the teaching forms are a common research subject, recognized as an element of a good inclusive practice, the goal was to indirectly measure this element by looking at the frequency of their usage in Serbian elementary schools. Results have shown that the frontal form is predominantly used, with a wide duration range in a single class. This is the case when we look at the class as a whole, and when we separate it on its introductory, central and the final part. The next most commonly used form (in all observation units) is the individual form, which in the central part of the class becomes used almost as often as the frontal form. Group form and its variations (teamwork and working in pairs) are the ones convincingly used the least. In terms of the dominance of the frontal form, Serbian schools do not differ from other countries on the account of the literature reviewed. The main finding here is also the subject of traditional class organization critique which accents the activity of the teacher, and it is based on the proved benefits of using group form(s) and the existence of numerous practical guidelines for its usage in classroom with or without pupils with impairments (Gödek 2004; Galton \& Williamson, 1992). 
Though the frontal form can be practical in terms of time-management and teacher's control, in the light of inclusion and the data on its overusage, it fails to answer new educational demands, mainly being the equal participation of each and every pupil in the construction of knowledge. In the introduction of this article strengths and weaknesses of each work form were presented, as well as the situations in which their application is appropriate. We have also put an emphasis on the positive effects of their combined use, mainly on peer relations, classroom climate and knowledge acquisition. Pupils with sensory impairments are most commonly exposed to the form that relies on perception and memory that does not allow for a lot of interaction and the activation of higher cognitive processes. This can negatively influence their subjective wellbeing (Keilmann, Limberger \& Mann, 2007). The weaknesses of the frotnal form can be mitigated with the appropriate usage of other forms and this is what the teachers should be informed about and encouraged to do. With such an implementation, they would not only advance their teaching skills, but provide all pupils with an experience of learning that is functional and life-long.

There are few limitations to present research. Not all the schools and grades were included in the sample, so the examples of extraordinary practice may be overlooked. In a way, that is the limit of descriptive methods and statistics themselves, which are used here exclusively. Registering frequency and duration is informative, but it can exclude other important factors that determine all aspects of usage of a certain work form. This should be kept in mind while judging the indicators of quality of an educational system. Further, the data on the effect that different forms of work have on the pupils with sensory impairments is not explicitly stated. The reason for this is the lack of literarure on such a specific topic, even though there are many manuals for working with this children in Serbia and other countries (Lazor, Marković i Nikolić, 2008; Suzić, 2008; Orleove, Sobsey i Silberman 2004).

Future research could investigate the quality of the frontal form in schools in more detail, e.g. does it meet the requirements of efficiency (see Bognar $i$ Kragulj, 2010). Because it is predominantly used, a qualitative study of its use could suggest new and more concrete guidelines for teachers. This applies to other work forms as well and can be explored longitudinally, possibly connecting work forms with schools success and other psychological correlates (e.g. academic self-efficacy). Research could also focus on the pupils, their satisfaction with work in class, their needs or the particularities of the communication between them and the teachers.

\section{CONCLUSION}

This research has pointed to the problematic area of a basic element of education: the process of learning. In the given educational setting, learning can be realized in many different ways and forms of work are only one of them. These findings can serve for an improvement of the pedagogical strategy in the inclusive environment that respects the principles of diversity, balance and adaptation to individual differences. The social nature of learning and the relevance of its enablement for the pupils with sensory impairments needs to be fully understood so that the idea of inclusion would in practice be really possible. The center of the idea of inclusion is a focus on the learning subject (Lewis $\&$ Norwich, 2005) and by overusing the frontal form of work in which an individual in essentially isolated, the realization of this idea becomes more difficult. However, the findings presented here should be taken as the current state of conditions on account of which changes are not only preferable, but possible.

\section{REFERENCES}

Alper, S. \& Ryndak, D. L. (1992). Educating students with severe handicaps in regular classes. The Elementary School Journal, 1, pp. 373-387.

Bligh, D. (1998). What's the use of lectures?. Exeter: Intellect Books.

Buljubašić Kuzmanović, V. \& Petrović, A. (2014). Teaching and lesson design from primary and secondary teachers' perspective. Život $i$ škola, 31 (1), pp. 76-90.

Dean, J. (2000). Improving children's learning: Effective teaching in the primary school. London: Taylor \& Francis.

Galton, M., Williamson, J. (1992). Group Work in the Primary Classroom. London: Routledge.

Gerard, H.D. \& Miller, N. (1975). School Desegregation: A Long-Range Study. New York: Plenum Press.

Gödek, Y. (2004). Research on group work and collaborative work and its implications for primary school teachers. Gazi Üniversitesi Kirşehir Eğitim Fakültesi, 5 (2), pp. 27-34.

Hallam, S., Ireson, J. \& Davies, J. (2013). Effective Pupil Grouping in the Primary School: A Practical Guide. New York: Routledge.

Hrnjica, S. (1997). Dete sa razvojnim smetnjama u osnovnoj školi. Beograd: Učiteljski fakultet.

Johnson, D., Johnson, R., Johnson, J. \& Andersen, D. (1976). Effects of Cooperative Versus Individualized Instruction on Student Presocial Behaviour, Attitudes towards Learning and Achievement. Journal of Educational Psychology 68, pp. 446-52. 
Keilmann, A., Limberger, A. \& Mann, J.W. (2007). Psychological and physical well-being in hearing-impaired children. International Journal of Pediatric Otorhinolaryngology, 71, pp. 1747-1752.

Kolak, A. (2012). Školska kultura kao čimbenik kvalitete škole. In: Hrvać, N, Klapan, A., ed., Pedagogija i kultura, 1st ed. Zagreb: Hrvatsko pedagogijsko društvo, pp. 226-239.

Kyriacou, C. (2009). Effective Teaching in Schools: Theory and Practice. Cheltenham: Nelson Thornes.

Lazor, M., Marković, S. \& Nikolić, S. (2008). Priručnik za rad sa decom sa smetnjama u razvoju. Novi Sad: Novosadski humanitarni centar.

Lewis, A. \& Norwich, B. (2005). Special Teaching For Special Children? Pedagogies For Inclusion: A Pedagogy for Inclusion. Berkshire: Open University Press.

Markić, I. (2014). Didaktička kultura škole i razvoj suradničkih kompetencija učenika u nastavnom procesu. Školski vjesnik, 64 (4), pp. 627-652.

Mattes, W. (2007). Nastavne metode - 75 kompaktnih pregleda za nastavnike i učenike. Zagreb: Naklada Ljevak.

Meyer, H. (2002). Didaktika razredne kvake-rasprave o didaktici, metodici i razvoju škola. Zagreb: Eduka.
Meyer, B., Haywood, N., Sachdev, D. \& Faraday, S. (2008). Independent Learning: Literature Review. London: Department for Children, Schools and Families Research Report 051.

Mitchell, D. (2008). What Really Works in Special and Inclusive Education - Using evidence-based teaching strategies. London: Publication City.

Orelove, F. P., Sobsey, D. \& Silberman, R. K. (2004). Educating Children with Multiple Disabilities: A Collaborative Approach. Baltimore: Brookes Publishing Company.

Radović, Ž.V. (2015). Rhetorice docens - standardi za primenu monološke metode u nastavi. Beograd: Zavod za udžbenike.

Rowland, S. (1987). An Interpretative Model of Teaching and Learning', in Pollard, A., ed. Children and their Primary Schools, London: Palmer Press.

Sadler, E.J. (2014). J. A. Comenius and the Concept of Universal Education. London: Routledge.

Slavin, R. E. (1987). Developmental and motivational perspectives on cooperative learning: A reconciliation. Child Development, 58 (5), pp. 1161-1167.

Terhart, E. (2001). Metode poučavanja i učenja. Zagreb: Educa. 